\title{
INTRATHECAL FIBRINOLYSIS WITH STREPTOKINASE IN TUBERCULOUS MENINGITIS
}

\author{
BY A. P. FLETCHER 1 \\ (From the Wright-Fleming Institute of Microbiology, and St. Mary's Hospital, \\ London, W. 2, England)
}

(Submitted for publication May 26, 1953; accepted July 1, 1953)

The introduction by Cathie (1) of intrathecal streptokinase to prevent and treat blockage of the cerebrospinal pathways led to hopes that the treatment of this serious complication might be greatly improved; and that prevention and removal of the exudate in this disease might shorten the course of treatment and render chemotherapy more effective. These hopes were sustained by later reports $(2,3)$. On the other hand, Eadie $(4,5)$ and Lorber (6), both with equal numbers of treated and control cases, were unable to demonstrate benefit from the use of intrathecal streptokinase. The value of streptokinase in the treatment of tuberculous meningitis is therefore debatable.

The demonstration by Tillett and Sherry (7) that streptokinase produced an active fibrinolytic system in the pleural cavity, and was of great clinical value in the treatment of clotted hemothorax (8) and empyema (9), suggested re-examination of its value in tuberculous meningitis. The success of these authors appeared in part to be due to the fact that they had shown active fibrinolytic enzyme to be present in the pleural fluids of their treated cases, and had used measurements of fibrinolytic activity to assess dosage and control treatment.

A difficulty encountered in the work on tuberculous meningitis has been the proper assessment of dosage to produce free lytic enzyme; in fact no adequate measurements were performed by any of the quoted authors. In view of these uncertainties, clinical trial is not a satisfactory method of approach in deciding the merits or demerits of this treatment, since the immediate clinical assessment of such cases is unreliable, and long term assessment takes at least two years.

A quantitative laboratory investigation of the system employed, therefore, seemed warranted in order to eliminate unfruitful methods of therapy. It has been shown $(10,11)$ that streptokinase has

1 At present: Merck International Research Fellow, Bellevue Medical Center, New York. no fibrinolytic properties but acts on a serum factor named plasminogen to form an enzyme with fibrinolytic properties named plasmin. However, specific antibodies to streptokinase exist in plasma, and may be increased by the injection of this substance, or may follow naturally occurring hemolytic streptococcal infection. The action of plasmin may be partially or completely inhibited by naturally occurring antiplasmins (Figure 1 ).

Measurements of the components of this system might be expected to supply the information which appears to be essential for the rational control of therapy.

Streptokinase (Lederle) as a consequence of its method of preparation contains a substantial quantity of streptodornase (streptococcal desoxyribonuclease). This enzyme has been shown to exert important therapeutic effects upon purulent exudates containing desoxyribose nucleoprotein (12, 13). Observations in this laboratory made upon meningeal exudate taken from autopsied cases of tuberculous meningitis have shown that this exudate is composed chiefly of fibrin and fibrinous material. Feulgen staining demonstrated comparatively small amounts of nucleoproteins, and in vitro experiment confirmed that fibrin lysing systems played a predominant role in the lysis of this material. For these reasons the effects of streptodornase have been ignored, and this communication deals solely with streptokinase action.

Similarly, since the action of the protease inhibititor known to contaminate streptokinase preparations appeared to be quantitatively unimportant in the concentrations of streptokinase used, this factor is not further considered.

\section{Units of measurement}

Units of streptokinase and plasminogen were those of Christensen (14). One Christensen unit of plasmin is the quantity of enzyme required to lyse in 30 minutes at $35^{\circ} \mathrm{C}$. a fibrin clot derived from $1 \mathrm{ml}$. of 0.2 per cent bovine fibrinogen. This 


\section{Enzyme Precursor (Plasminogen) + Activator (Streptokinase) Enzyme (Plasmin) \\ Lyses Fibrin, etc.}

Fig. 1. Scheme of System

unit will lyse approximately $0.5 \mathrm{mg}$. of pure human fibrin under the same conditions.

One unit of antiplasmin is the amount of inhibitor that will prevent the fibrinolytic action of 1 unit of enzyme after 10 minutes incubation at $35^{\circ}$ C. Experiment showed that 95 per cent of the antiplasmin activity was fixed at the end of this time.

When measuring plasminogen it is assumed, under the favorable experimental conditions employed, that complete conversion to plasmin occurs. The inaccuracies inherent in this assumption and in the method have been stated previously (14).

The system of measurement then becomes:

One unit of plasminogen when activated becomes one unit of plasmin which is inhibited by one unit of antiplasmin.

Assay methods for plasmin involving a substantial degree of dilution will demonstrate enzyme which is not available for fibrinolysis, since the effect of non-specific inhibition is altered by dilution (15). The method of assay for plasmin employed in this investigation requires minimal dilution, arid measures only the "free" enzyme available for fibrinolysis with an accuracy \pm 10 per cent (15). The unit of enzyme activity is a substantial one, and it is probable that a level of activity equivalent to 1 plasmin unit per ml. C.S.F. is adequate for the requirements of therapy in the cerebrospinal spaces.

\section{METHODS}

Plasminogen was estimated by the original Christensen (14) technique, with the modification that, where a more accurate figure was required, a second titration with a narrower range of dilution about the point of 1 unit activity was performed. Plasmin, antiplasmin, and the required dosage of streptokinase were estimated by the methods of Fletcher (15). Streptokinase antibodies were not found to exert much influence in fluids of the cerebrospinal spaces and were not estimated as a routine; when required, a modification of the Christensen (14) technique was used.

\section{RESULTS}

\section{Plasminogen content of the cerebrospinal fluid in tuberculous meningitis}

Since streptokinase is inactive in the absence of plasminogen, 71 determinations were made on specimens of C.S.F. from 26 cases of tuberculous meningitis. The findings are illustrated in Table I, along with estimations on normal lumbar C.S.F.

It is seen that enzyme precursor is present in much greater amounts than occurs in normal C.S.F. Noteworthy differences in plasminogen content between ventricular and lumbar fluids are present. Cases suffering from spinal block showed in lumbar fluids taken from below the block extremely high plasminogen levels, in some cases as great as those found in the serum. High plasminogen values were found in association with high levels of C.S.F. protein, although the correlation coefficient did not reach the level of statistical significance.

\section{Antiplasmin content}

The inhibitor content of 28 specimens of C.S.F. from 18 cases with tuberculous meningitis are recorded together with normal findings in Table II. It is seen that inhibitor is present in every fluid examined, and that significant differences are again apparent between ventricular and lumbar fluids. The inhibitor content of these fluids appears to be low when compared with their plasminogen content. However the interactions of the other components of the system result in these inhibitor contents exerting a significant effect upon the difficulties of inducing fibrinolytic activity.

TABLE I

Plasminogen content of C.S.F.

\begin{tabular}{|c|c|c|}
\hline $\begin{array}{l}\text { Site of withdrawal } \\
\text { and number of } \\
\text { fluids }\end{array}$ & $\begin{array}{c}\text { Average } \\
\text { plasminogen } \\
\text { content } \\
\text { units/ml. }\end{array}$ & $\underset{\text { units } / m l .}{\text { Range }}$ \\
\hline $\begin{array}{ll}\text { Normal lumbar } & (10) \\
\text { Ventricular } & (29) \\
\text { Lumbar } & (34) \\
\text { Lumbar } & (8) \\
\text { (spinal block) }\end{array}$ & $\begin{array}{r}6 \\
20 \\
50 \\
500\end{array}$ & $\begin{array}{rr}2- & 16 \\
2- & 64 \\
16- & 128 \\
250-1,000\end{array}$ \\
\hline
\end{tabular}


TABLE II

Inhibitor content of C.S.F.

\begin{tabular}{|c|c|c|}
\hline $\begin{array}{l}\text { Site of withdrawal } \\
\text { and number of } \\
\text { fluids }\end{array}$ & $\begin{array}{c}\text { Average } \\
\text { antiplasmin } \\
\text { content } \\
\text { units } / m l .\end{array}$ & $\underset{\text { units } / m \text { ml. }}{\text { Range }}$ \\
\hline \begin{tabular}{l} 
Normal lumbar $(12)$ \\
Ventricular \\
Lumbar \\
Lumbar \\
\multicolumn{1}{c}{ (12)inal block) }
\end{tabular} & $\begin{array}{r}0.5 \\
1.5 \\
5 \\
13\end{array}$ & $\begin{array}{r}0.5-5 \\
1.5-8 \\
11-16\end{array}$ \\
\hline
\end{tabular}

Though the antiplasmin content of cerebrospinal fluid tends to rise with increasing protein levels, the correlation does not reach the level of statistical significance.

\section{Transformation of plasminogen to plasmin by streptokinase}

The addition of increasing concentrations of streptokinase to biological fluids results in an increase of plasmin activity until with high concentrations a plateau of activity is reached; the lowest concentration of streptokinase inducing the maximal enzyme activity has been designated the "optimal" streptokinase concentration. It has been shown that the "optimal" dose of streptokinase does not result in complete conversion of plasminogen to plasmin (15). These measurements were made on a partly purified plasminogen preparation containing negligible amounts of inhibitor and with an activity corresponding to 5,000 Christensen units per mg.N. Figure 2 shows that when the "optimal" concentration of streptokinase is employed, a high conversion of precursor to enzyme occurs at low precursor concentrations, but that at high precursor concentrations the conversion rate becomes low. The effect of this inefficient transformation of plasminogen to plasmin is to reduce considerably the potential enzyme activity of fluids of high precursor content. This increases the relative importance of the apparently low antiplasmin content of the C.S.F., so that fluids of high plasminogen content have only a small lytic potentiality.

\section{Maximal plasmin activity}

A number of factors unfavorable to the appearance of "free" fibrinolytic enzyme have been discussed. It was thought that these factors, the presence of streptokinase antibodies, the inefficiency of streptokinase activation, and the content of anti-

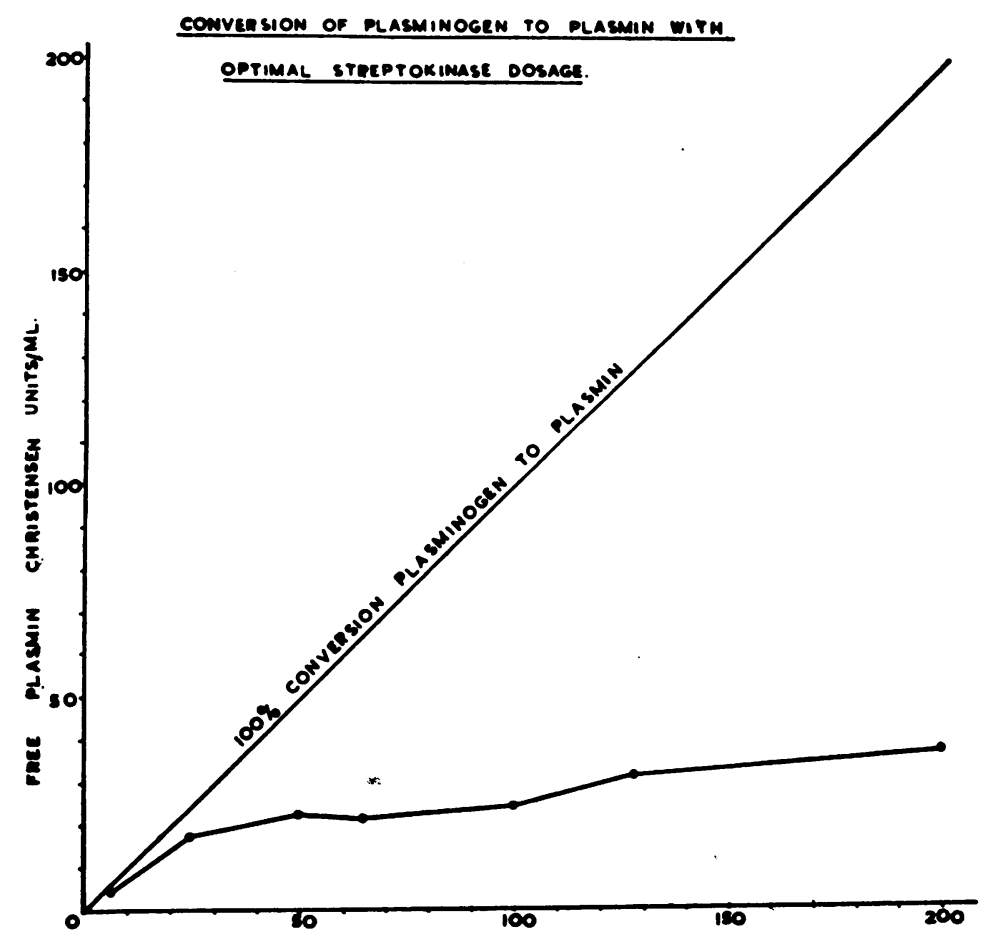

Fig. 2. Available Plasminogen Christensen Units/Ml. 
TABLE III

Plasmin levels with optimal streptokinase

\begin{tabular}{|c|c|}
\hline $\begin{array}{l}\text { Site of withdrawal } \\
\text { and number of } \\
\text { fluids }\end{array}$ & $\begin{array}{l}\text { Range of } \\
\text { enzyme } \\
\text { potency } \\
\text { plasmin } \\
\text { units } / \mathrm{ml} \text {. }\end{array}$ \\
\hline \begin{tabular}{lr} 
Normal lumbar & $(10)$ \\
Ventricular & $(10)$ \\
Lumbar & $(19)$ \\
Lumbar & $(7)$ \\
\multicolumn{1}{c}{ (spinal block) }
\end{tabular} & $\begin{array}{ll}0.25-1.5 \\
1 & -3 \\
1.5 & -5 \\
1 & -2.5\end{array}$ \\
\hline
\end{tabular}

plasmin might result in a complete suppression of fibrinolytic activity even with optimal amounts of streptokinase. Titrations of 56 cerebrospinal fluids from 23 patients were made with varying amounts of streptokinase ; in each case free fibrinolytic enzyme was shown to be present provided that a suitable amount of streptokinase was added to the fluid. It was found that where insufficient streptokinase was used, the unfavorable factors resulted in a complete suppression of fibrinolytic activity. This implies a minimum streptokinase concentration below which physiologically active enzyme is not released, and below which clinical effects attributable to fibrinolysis cannot be expected. Table III shows the maximum enzyme ranges recorded in 36 cerebrospinal fluids from 18 patients where the "optimal" amount of streptokinase was employed. It is seen that despite the wide variations in plasminogen and inhibitor content demonstrated previously, the potential lytic potency of fluids from different sites is very similar.

\section{The clinical requirement of streptokinase}

The C.S.F. enzyme levels in Table III were obtained using streptokinase concentrations of 25 to 100 units per ml. C.S.F. for the ventricular and lumbar fluids, and 100 to 500 units per ml. C.S.F. for the lumbar fluids taken below spinal blocks. These streptokinase concentrations would be unsafe to use clinically, since assuming a C.S.F. volume of $120 \mathrm{ml}$. the intrathecal dose would be 2,500 to 15,000 units streptokinase.

It was decided to investigate a lower level of activity, and Table IV shows the concentration of streptokinase required to induce 1 unit of plasmin activity per ml. C.S.F. Table IV shows that a lower concentration of streptokinase is required to activate ventricular fluid than lumbar fluid; this difference is in line with the other differences in composition noted in Tables I to III. Ventricular fluids required 1.5 to 30 units streptokinase per $\mathrm{ml}$. C.S.F. to produce an enzyme potency of 1 unit per $\mathrm{ml}$. C.S.F., lumbar fluids required 3 to 60 units streptokinase per ml. C.S.F., while lumbar fluids from below spinal block required 30 to 120 units streptokinase per ml. C.S.F. to produce the same lytic potency. For 45 out of 58 fluids the ineffective streptokinase concentration was one step below that required for 1 unit activity, i.e., if a fluid required 10 units streptokinase per $\mathrm{ml}$. C.S.F. for 1 unit of enzyme activity, 6 units streptokinase per ml. C.S.F. produced no free enzyme. For 17 fluids the ineffective dose was two steps below the dose required for 1 unit of enzyme activity (see Table IV).

These differences in composition between ventricular and lumbar fluids render it difficult to calculate the clinical dose. Since cisternal fluid more nearly resembles ventricular than lumbar fluid, the dose for each patient was calculated on the assumption that the ventricular fluid assay represented a true sample of $80 \mathrm{ml}$. C.S.F. and the lumbar fluid represented a sample of $40 \mathrm{ml}$. The use of this simplification suggested that where the cerebrospinal circulation was free, 90 per cent of patients would require an intrathecal dose varying between 300 and 3,000 units of streptokinase; in practice the dose was calculated individually for each patient. Though fluids with a high protein content required large doses of streptokinase for their activation, and fluids of low protein content small doses, the correlation coefficient did not reach the level of statistical significance.

TABLE IV

Number of fluids showing at least 1 unit of plasmin activity with various streptokinase concentrations

\begin{tabular}{llllllllll}
\hline \hline $\begin{array}{c}\text { Streptokinase } \\
\text { units/ml. }\end{array}$ & 0 & 1.5 & 3.0 & 6.0 & 10 & 15 & 30 & 60 & 120 \\
\hline $\begin{array}{c}\text { Number of } \\
\text { ventricular } \\
\text { fluids (24) }\end{array}$ & 0 & 3 & 11 & 15 & 22 & 23 & 24 & \\
$\begin{array}{c}\text { Number of } \\
\text { cisternal } \\
\text { fluids (10) }\end{array}$ & 0 & 2 & 5 & 7 & 10 & & & & \\
$\begin{array}{c}\text { Number of } \\
\text { lumbar } \\
\text { fluids (18) }\end{array}$ & 0 & 0 & 3 & 5 & 10 & 15 & 15 & 18 & \\
$\begin{array}{c}\text { Number of lumbar } \\
\text { fluids below } \\
\text { spinal block (8) }\end{array}$ & 0 & 0 & 0 & 0 & 0 & 0 & 1 & 3 & 8 \\
\hline
\end{tabular}


Correlation between in vivo and in vitro enzyme activity

Where a number of unknown factors exist, calculations made from in vitro testing must be confirmed by in vivo experiment. It was realized in making this comparison that inaccuracies connected with sampling and estimation of C.S.F. volumes had occurred, but it was believed that the results were sufficiently informative to be valuable.

Table V shows the calculated enzyme activity, the calculated streptokinase concentration, and the enzyme activity obtained by sampling.

The calculated in vivo enzyme level was ascertained by in vitro titrations on samples of ventricular and lumbar fluids from the patient, activated with varying quantities of streptokinase. Suitable concentrations of streptokinase to give equal activities in lumbar and ventricular samples having been found, the dose for injection was calculated on the assumption that ventricular fluid represented a volume of $80 \mathrm{ml}$. C.S.F. and lumbar fluid represented a sample of $40 \mathrm{ml}$. C.S.F. The calculated in vivo streptokinase concentration in units per ml. was then obtained by dividing the total dose of streptokinase by 120 .

When the ventricular or cisternal route was used for injecting the streptokinase, ventricular and cisternal samples were withdrawn at 10 and 30 minutes after injection from both sites. The highest level of enzyme activity obtained from

TABLE V

Enzyme assays of C.S.F. after intrathecal injection of streptokinase. Comparison with levels suggested by in vitro testing

\begin{tabular}{ccc}
\hline \hline $\begin{array}{c}\text { Calculated } \\
\text { in vivo } \\
\text { strepto- } \\
\text { kinase } \\
\text { concen- } \\
\text { tration } \\
\text { units/ml. }\end{array}$ & $\begin{array}{c}\text { Calculated } \\
\text { in vivo } \\
\text { enzyme } \\
\text { level } \\
\text { (from in vitro } \\
\text { testing) } \\
\text { units/ml. }\end{array}$ & $\begin{array}{c}\text { Actual } \\
\text { in vivo } \\
\text { enzyme } \\
\text { level } \\
\text { determined } \\
\text { by sampling } \\
\text { units/ml. }\end{array}$ \\
\hline 500 & 2.6 & $<0.1$ \\
200 & 3.0 & $<0.1$ spinal \\
200 & 1.7 & $<0.1$ blocks \\
50 & 0.5 & $<0.1$ \\
50 & 1.4 & $<0.1$ \\
50 & 2.8 & $<0.1$ \\
50 & 3.2 & $<0.1$ \\
34 & 1.9 & $<0.1$ \\
30 & 2.2 & 0.5 \\
25 & 1.3 & 0.8 \\
20 & 1.8 & 1.0 \\
10 & 1.5 & 0.5 \\
8 & 2.0 & 1.0 \\
5 & 1.0 & 0.8 \\
\hline
\end{tabular}

these samples was regarded as the in vivo enzyme level. A few samples were obtained two hours after injection, but these samples invariably showed much less activity than earlier samples. In cases where streptokinase was injected below a spinal block, the volume of the fluid below the block was determined by the phenolsulphonephthalein dilution method, and the dose of streptokinase was found using this volume as a basis for calculation.

Though the error of sampling by these procedures would be very large, earlier work (15) had shown that the quantity of enzyme activity produced in C.S.F. was not proportional to the concentration of streptokinase, but approximately proportional to the log concentration of streptokinase, and this relationship would do much to minimize errors due to incomplete distribution.

It might be expected that adsorption of fibrinolytic enzymes onto fibrin would occur in vivo and thus give rise to spuriously low levels of enzyme on sampling. The importance of this factor was investigated by means of in vitro tests with models.

It can be calculated that in the spinal meninges, the maximum ratio of meningeal surface to C.S.F. volume is approximately $4 \mathrm{sq}$. $\mathrm{cm}$. of surface to $1 \mathrm{ml}$. of C.S.F. The general ratio of meningeal surface to C.S.F. volume is much less than this, and in addition only a part of this surface would be covered with fibrin. Glass tubing of $4 \mathrm{~mm}$. bore provides a surface to volume ratio of $1 \mathrm{sq}$. $\mathrm{cm}$. per $1 \mathrm{ml}$. Thirty $\mathrm{cm}$. lengths of $4 \mathrm{~mm}$. glass tubing were coated with fibrin by introducing 0.4 $\mathrm{ml}$. of fibrinogen thrombin mixture (containing $12 \mathrm{mg}$. bovine fibrinogen) along the bore of the tube with a fine pipette and rotating the tubes rapidly in the chuck of an electric motor until clotting had occurred. Assays conducted on samples of streptokinase activated C.S.F. respectively incubated in fibrin coated and similar glass tubes revealed negligible differences over the range 3.0 to 0.3 units per ml. plasmin. It was concluded that over this range of enzyme activity adsorption onto fibrin in vivo would not increase the sampling error.

Table V shows that a great disparity exists between the enzyme level calculated on the basis of in vitro testing and the enzyme level actually found in vivo. For instance, the first line of the table shows that in a fluid taken below a spinal block 
the calculated streptokinase level was 500 units per ml. which on in vitro testing should have provided an in vivo level of 2.6 enzyme units per $\mathrm{ml}$. The actual level as determined by in vivo sampling was $<0.1$ units per $\mathrm{ml}$. In cases where large doses of streptokinase were injected below spinal blocks no free fibrinolytic enzyme was produced, and in fact in cases where large doses of streptokinase were shown to be necessary by in vitro testing the enzyme level was most disappointing. In cases where in vitro testing had indicated that a small dose of streptokinase could be used with success, the disparity between the calculated and the actual enzyme level found on sampling was not great; for instance the bottom line of Table V shows that the calculated enzyme level with 5 units of streptokinase per ml. C.S.F. was 1 unit per ml., and the actual level found on sampling was 0.8 unit per $\mathrm{ml}$. It is apparent that the use of high concentrations of streptokinase in the spinal theca frequently results in most disappointing enzyme levels, while the use of low concentrations of streptokinase is usually much more successful.

The reasons for this discrepancy are interesting and important. The evidence points strongly to the fact that streptokinase in high concentrations exerts an irritative effect upon the spinal theca resulting in the in-flow of serous fluid with a resulting high concentration of inhibitor. Assays in four cases, where free fibrinolytic enzyme had not been demonstrated after high streptokinase dosage, showed that the antiplasmin value had increased over 40 per cent in each case. Such an increase in inhibitor would account for the fact that fibrinolytic enzyme could not be demonstrated in vivo. Though it was realized that fresh plasminogen would also enter the C.S.F. with the inhibitor, inspection of the data in Tables I and III shows that this material would exert comparatively little effect. The practical value of this observation is clear; it indicates that the intrathecal injection of streptokinase may exert, in the absence of demonstrable clinical upset, an irritative effect upon the spinal theca, which is sufficient to nullify its potential therapeutic action.

The effect of a single streptokinase injection upon the C.S.F. plasminogen level

Since the effect of streptokinase is to convert enzyme precursor to enzyme, there may be a fall
TABLE VI

Plasminogen level following streptokinase injection

\begin{tabular}{ccc}
\hline \hline $\begin{array}{c}\text { Initial } \\
\text { plasminogen } \\
\text { level }\end{array}$ & $\begin{array}{c}\text { Level } \\
\text { 6hours } \\
\text { after } \\
\text { streptokinase }\end{array}$ & $\begin{array}{c}\text { Level } \\
\text { 44 hours } \\
\text { after } \\
\text { activation }\end{array}$ \\
\hline 256 & 64 & 128 \\
128 & 64 & 256 \\
128 & 4 & 32 \\
64 & 4 & 32 \\
32 & 2 & 16 \\
\hline
\end{tabular}

in precursor level following an injection of streptokinase. Table VI shows the extent of the fall and the rate of recovery to the former plasminogen level; these observations refer to patients with a free cerebrospinal circulation. It is seen that though an early fall in level is apparent, this fall is temporary, and the level has largely returned to its former state in 24 hours. These findings suggest that if a period of 24 hours is allowed to elapse between the first and the next streptokinase injection, the effect of the last injection will not be hindered by lack of precursor. In patients with various types of cerebrospinal blockage the situation is far from simple, and the results in such cases have not been tabulated owing to their inconstant pattern and the multiplicity of factors at work.

\section{DISCUSSION}

Streptokinase may be employed under three distinct circumstances in the therapy of tuberculous meningitis, and these circumstances profoundly influence the nature of its employment and the chances of success with its use. These uses are (a) prophylactically before obstruction of the cerebrospinal pathways has occurred, $(b)$ for the therapy of established or pending subtentorial and basal cistern block and (c) for the therapy of spinal block.

Streptokinase has been employed as a prophylactic measure in therapy by most workers. The findings reported here demonstrate that the routine use of a dose of 100 Christensen units (600 Cathie units) streptokinase will fail to produce free enzyme in a substantial proportion of cases. The optimal dose for intrathecal treatment appears to lie in the range 300 to 3,000 units, with the majority of patients requiring doses at the lower end of the range. Unfortunately the optimal dose can only be gauged by laboratory assay. It is how- 
ever certainly possible, and probably desirable, to use streptokinase in this manner provided its use is controlled by laboratory assay.

The investigations of Lorber (16) have revealed the high incidence and dire consequences of subtentorial block, and it has also been our personal experience that this complication is responsible for much mortality and morbidity.

Despite the recognition of this complication clinically, and the possibility of controlling the resultant hydrocephalus by ventricular drainage, the end results of treatment are poor. It would appear that streptokinase may prove effective in lysing the fibrin producing the block, since the enzyme can be placed in close proximity to the lesion by cisternal puncture, and assays on cisternal fluid have shown that lytic activity can be induced by small doses of streptokinase. The wisdom of leaving treatment with lytic factors to this stage is doubtful.

The easily diagnosed complication of spinal block exerts a considerable fascination for those wishing to assess the effect of fibrinolytic therapy owing to the ease with which the progress of treatment can be ascertained. Assay of lumbar fluids taken from below spinal blocks has demonstrated that the problem presents peculiar difficulties. The antiplasmin content of the lumbar fluids ranged from 11 to 16 units ; the dose of streptokinase which fails to produce free enzyme may be as high as 34 units streptokinase per ml. C.S.F.; the concentration required to produce 1 unit of plasmin per $\mathrm{ml}$. may be double this figure, while the range of dose for optimal activation is higher still. In vivo assay has previously shown that unsatisfactory results occur when dosage of this order is suggested by in vitro testing. The clinical experience may be briefly summarized by the statement that 25 attempts to lyse nine spinal blocks have been made and only one temporary success resulted. It was concluded that streptokinase alone on the basis of in vitro testing and clinical trial is an unsatisfactory agent for the treatment of spinal block.

\section{SUM MARY}

Examination of the components of the plasminogen plasmin system present in the cerebrospinal fluids of patients suffering from tuberculous meningitis suggests that the injection of streptokinase is capable of inducing useful concentrations of fibrinolytic enzyme. The concept of a lower limit of effective dosage below which, owing to the presence of inhibitors, no free fibrinolytic enzyme is produced, has been advanced. It has also been shown that an upper limit of intrathecal dosage is also present, since not only will high concentrations of streptokinase produce systemic upsets, but the local irritation of the spinal theca will result in the failure of such therapy. Laboratory examination of the cerebrospinal fluid is essential to the estimation of the correct intrathecal dose.

It has been shown that the customary dose of streptokinase used for intrathecal treatment (100 Christensen Units) will usually be insufficient to produce free fibrinolytic enzyme. The variation between individual patients is considerable, but the optimal dose for intrathecal treatment usually lies between 300 to 3,000 units of streptokinase; a standard dose cannot be stated. It is believed that these experiments indicate the reason for the variable clinical results obtained by various workers.

These investigations indicate that streptokinase may be used with reasonable chances of success, either prophylactically, or for the treatment of subtentorial or basal cistern block; the chances of successful treatment of spinal block by this means are small.

\section{ACKNOWLEDGMENTS}

I am indebted to Professor Sir Alexander Fleming and Professor Robert Cruickshank for much encouragement and helpful criticism. I also thank Dr. W. D. W. Brooks for advice in the clinical management of the cases; $\mathrm{Mr}$. J. Tobar for excellent technical assistance in the laboratory; and the Director of Lederle Laboratories Division for a generous gift of "Varidase" streptokinase-streptodornase, and supplies of "Clotting Globulin."

\section{REFERENCES}

1. Cathie, I. A. B., Bacterial fibrinolysin, its possible therapeutic application in tuberculous meningitis. J. Clin. Path., 1949, 2, 73.

2. Cathie, I. A. B., Streptomycin-streptokinase treatment of tuberculous meningitis. Lancet, 1949, 1, 441.

3. Cathie, I. A. B., and MacFarlane, J. C. W., Adjuvants to streptomycin in treating tuberculous meningitis in children. Lancet, 1950, 2, 784.

4. Eadie, M. B., cited in Scottish fever group. Brit. M. J., 1950, 2, 1050. 
5. Eadie, M. B., Personal communication, 1952.

6. Lorber, J., Streptokinase as an adjunct in the treatment of tuberculous meningitis. Lancet, 1951, 1, 1334.

7. Tillett, W. S., and Sherry, S., The effect in patients of streptococcal fibrinolysin (streptokinase) and streptococcal desoxyribonuclease on fibrinous, purulent, and sanguinous pleural exudations. J. Clin. Invest., 1949, 28, 173.

8. Sherry, S., Tillett, W. S., and Read, C. T., The use of streptokinase-streptodornase in the treatment of hemothorax. J. Thoracic Surg., 1950, 20, 393.

9. Tillett, W. S., Sherry, S., and Read, C. T., The use of streptokinase and streptodornase in the treatment of chronic empyema. J. Thoracic Surg., 1951, 21, 325.

10. Milstone, H., A factor in normal human blood which participates in streptococcal fibrinolysis. J. Immunol., 1941, 42, 109.

11. Christensen, L. R., and MacLeod, C. M., A proteolytic enzyme of serum: Characterization, activation, and reaction with inhibitors. J. Gen. Physiol., 1945, 28, 559.

12. Sherry, S., Tillett, W. S., and Christensen, L. R., Presence and significance of desoxyribose nucleoprotein in the purulent pleural exudates of patients. Proc. Soc. Exper. Biol. \& Med., 1948, 68, 179.

13. Sherry, S., Johnson, A., and Tillett, W. S., The action of streptococcal desoxyribose nuclease (streptodornase) in vitro and on purulent pleural exudations of patients. J. Clin. Invest., 1949, 28, 1094.

14. Christensen, L. R., Methods for measuring the activity of components of the streptococcal fibrinolytic system, and streptococcal desoxyribonuclease. J. Clin. Invest., 1949, 28, 163.

15. Fletcher, A. P., Measurement of the components of the plasminogen plasmin system in biological fluids. Biochem. J., 1953.

16. Lorber, J., Studies of the cerebrospinal fluid circulation in tuberculous meningitis in children. Part II. A review of 100 pneumocephalograms. Arch. Dis. Child., 1951, 26, 28. 